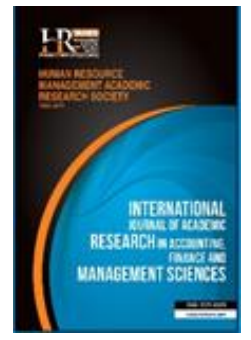

International Journal of Academic Research in Accounting, Finance and Management Sciences

Vol. 8, No.3, July 2018, pp. 37-44

E-ISSN: 2225-8329, P-ISSN: 2308-0337

(c) 2018 HRMARS

www.hrmars.com

To cite this article: Sorunke, O.A. (2018). Forensic Accounting Investigation Techniques and Successful Prosecution of Corruption Cases in Nigeria, International Journal of Academic Research in Accounting, Finance and Management Sciences 8 (3): 37-44.

\title{
Forensic Accounting Investigation Techniques and Successful Prosecution of Corruption Cases in Nigeria
}

\section{Olukayode Abayomi SORUNKE}

International Institute for Forensic Accounting Research and Development. (IIFARD), New Jersey, E-mail: sorunke@yahoo.com

\begin{abstract}
With the upsurge in the loss of high profile corruption cases by the anti-corruption agencies in Nigeria, resulting from the inability of the prosecutors to come before courts with legally acceptable evidence, the adoption of forensic accounting investigation techniques in corruption investigation and prosecution has become imperative. The objective of this study is to examine the potency of forensic accounting investigation techniques in corruption investigation and prosecution in Nigeria. The survey design was used in the study with sample population consisting of investigators and prosecutors drawn from the four anti-corruption agencies in Nigeria (Economic and Financial crimes commission (EFCC), Independent Corrupt Practices Commission (ICPC), Code of conduct Bureau (CCB) and Police Special Fraud Unit (PSFU). The Yamane's formular was used in the determination of the sample size. The technique adopted for analysis of returned questionnaires include descriptive and inferential statistical methods, while Kolmogorov-Smirnov test was used to test the only hypothesis formulated for the study. The findings form the study indicates that there is a significant and positive relationship between the adoption of forensic accounting investigation techniques in corruption investigation and successful prosecution of corruption cases in Nigeria. It was therefore recommended that all the anti-corruption agencies in Nigeria should always adopt forensic accounting investigation techniques in all their corruption investigation so as to be able to come up with evidences that will be supportive in prosecution of corruption cases in courts.

Key words

Forensic accounting, corruption, anti-corruption agencies

Received: 25 Jun $2018 \quad$ (C) The Authors 2018

Revised: 20 Jul $2018 \quad$ Published by Human Resource Management Academic Research Society (www.hrmars.com)

Accepted: $28 \mathrm{Jul} 2018 \quad$ This article is published under the Creative Commons Attribution (CC BY 4.0) license. Anyone may Published Online: 15 Aug 2018 reproduce, distribute, translate and create derivative works of this article (for both commercial and noncommercial purposes), subject to full attribution to the original publication and authors. The full terms of this license may be seen at: http://creativecommons.org/licences/by/4.0/legalcode
\end{abstract}

\section{Introduction}

The rise in the menace of public sector corruption in Nigeria with its negative attendance on national economic and development has become a relevant discourse of our time. This maladies called corruption seems to be in an escalating rate as we witness it day-in-day-out, through newspaper reportage that public officers and treasury managers entrusted with public treasury, manage business to their own advantage. It is no longer a news in Nigeria that public treasury is been looted in millions, billions and in trillions with rapacity of a glutton.

Corruption is a global phenomenon that raises concern worldwide. It related to social, economic and political conditions and it is considered to be a most dangerous and destabilizing phenomenon. Corruption in public sector includes crime, such as bribery of public officials, embezzlement, infringement of public property, evasion of public bidding in public contract, nepotism, favourism and clanishnent in the awarding of public contract, trading in influence, sub-contracting, illicit enrichment, illegal payment, money 
laundering, false asset declaration, under payment, window dressing in books of accounts, concealment, aiding and abetting of all kinds to the detriment of another person, party, community, society or nation.

As alluded earlier corruption is a global phenomenon. It exist throughout the world, in industrialized and developing nations alike, but the only difference is that the prevalence, gravity, dimension and persistence vary from one society or the other. Here in Nigeria the menace of corruption is so endemic. It has for a long time remained one of the most debilitating issues facing post-independence Nigeria. Corruption among public officials has remained the bane of Nigeria for many years. It is so worrisome that every meaningful effort put in place by anti-corruption agencies in Nigeria today to check the malady seem to be proving abortive as many of the politically corrupt officials' often get away with their loots even in the law courts.

Adegbite and Fakile (2012) in their own submission posit that non-availability of appropriate litigation support services in the court has led to misjudgment or incorrect submission by lawyers and judges. Hence offenders are not given appropriate punishment because the gravity or extent of economic loss or damages cannot be adequately determined. Obasanjo (2017) hit the nail on the head when he posited that lack of successful prosecution of high profile corruption cases involving some politically exposed persons are giving a serious cause of concern both for Nigerians and international community.

No doubt, the ability of anti-corruption investigators and prosecutors to come up with legally acceptable evidence is very fundamental to successful prosecution of corruption cases in anywhere in the world. Today the general consensus among scholars, researchers and practitioners is that forensic accounting investigation techniques can offer some respite to successful prosecution of corruption cases in the court than the conventional accounting and auditing system can do.

Forensic accounting is a new evolving branch of accounting practice which involves the application of specialized skills in accounting, finance, quantitative method, law and research in the collection, analysis, interpretation and evaluation of financial evidence to support criminal proceedings. According to Bhasin cited in Modugu and Anyanduba (2013) the objectives of forensic accounting includes; the assessment of damages caused by an auditor's negligence, fact findings to see whether an embezzlement has taken place, in what amount and whether criminal proceeding are to be initiated; collection of evidence in the criminal proceeding.

\subsection{Statement of problem}

The high level of fraud and corruption experienced in Nigeria public sector has now reached an alarming stage. It is so worrisome that the ability of public sector auditors (both internal and external) and traditional auditing method to checkmate these maladies called fraud and corruption has attracted public concern. Public sector corruption in Nigeria is so alarming that it has imposed huge pressure on anticorruption agencies and corporate regulators. Indeed, it has also led inevitably, to pressure for better internal control system; improved auditing techniques and enhanced professional accounting standards if the accounting profession still want to be relevant as a noble profession.

The failure of internal auditing system of organization in identifying accounting fraud has led to the use of specialized procedures to detect financial accounting fraud, collectively known as forensic accounting (Sharma and Panigrahi 2012). While considerable literatures has been developed on the definition of forensic accounting as well as the skill requirements for forensic accountants for fraud investigation (Harris and Brown, 2000; Gippo and Ibex, 2003; Messmer, 2004; Hoopwood et al.,2008; DiGabriel, 2009; Davis et al., 2010; Ramaswamy, 2011; Bhasin, 2013 , and Azih and Okoli, 2015), little has been written on the potency of forensic accounting investigation techniques in successful prosecution of corruption cases in law court. Therefore the essence of this study is to contribute toward filling this gap.

\subsection{Research Question}

Specifically this study will attempt to provide answer to the only research question raised below;

Is there any significant and positive relationship between the adoption of forensic accounting techniques in corruption investigation and the successful prosecution of corruption cases in the court? 


\subsection{Statement of Hypothesis}

In realization of the objective of this study, the hypothesis stated below was formulated and tested;

$\mathrm{H}_{1}$ Adoption of forensic accounting techniques in corruption investigation has no significant and positive relationship with successful prosecution of corruption cases in law courts.

\section{Literature review}

\subsection{Concept of forensic accounting}

The concept, forensic accounting means different things to different people. There is no unanimity among scholars and accounting practitioners regarding the meaning of the concept. Hence, there is no generally adopted definition of forensic accounting. There are many definitions as there are many authors. However, there is a consensus on the fact that Maurice Peloubert, a partner in an accounting firm in New York is credited with the developing the term "forensic accounting" in his 1946 essay "forensic accounting: its place in today's economy".

According to Adegbie and Fakile (2012) forensic accounting is practice of utilizing accounting, auditing and investigation skill to assist in legal matter and application of specialized body of knowledge to the evidence of economic transaction and reporting, suitable in the purpose of establishing accountabilities or valuation of administrative proceedings. In the view of Bologna and Lindguist cited in Omar and Jomitin (2013) forensic and investigative accounting is the application of financial skill and investigative mentality to resolve issues conducted within the context of rule of evidence. As a discipline, it encompasses financial expertise, fraud knowledge and understanding of business reality and working of legal system.

Sukumal (2014) opined that forensic accounting, forensic accountancy or financial forensic is the specialty practice area of accounting that describe engagements that result from actual or anticipated dispute or litigation. Chattopadhyay (2014) on his own part defined forensic accounting as encompasses all accounting and financed analyses performed for assisting counsel in connection with investigation assessment and proof of issues in a dispute resolution proceeding.

According to Hopwood, Leiner and Young cited in Ramadhan (2015), forensic accounting is defined as an accounting specialization in which investigation and analytical skills are applied for the purpose of resolving financial issues in a manner that meets standard required by court of law. In the view of Dhar and Sarkar cited in Sorunke (2016) forensic accounting is the application of accounting concepts and techniques to legal problems. It demands reporting where fraud, bribery or embezzlement is established and the report is considered as evidence in the court of law or in administrative proceeding.

In a nutshell, forensic accounting can best be described as the application of auditing, accounting, statistics, research and economic concept and techniques in investigation with the sole aim of solving legal problem or potential problem in form of bribery, fraud, embezzlement, corruption and forgery that may occur from economic or financial transaction. It is therefore pertinent that the who-be forensic accountant engaging in forensic accounting assignment or investigation must understand the legal process because the forensic accounting engagement may lead to court action, requiring the professional forensic accountant to stand in as expert witness before the court to give evidence to assist the court in resolving legal issues.

\subsection{Concept of Corruption}

Corruption as a term has been perceived in various ways by various Scholars. Its conceptualization has attracted in recent past competing and numerous views and approaches. This has to some extent, complicated the attainment of a definitional uniformity on the concept within the academic and practicing world of administration. (Adeyemi, 2012)

Even dictionary definitions of corruption vary; the Webster's dictionary defines corruption as "inducement (as of a political official) by means of improper consideration (as bribery) to commit a violation of duty". The Oxford Dictionary definitions are broadly similar, but with stronger echoes of other meanings, in the Oxford version, corrupt means "to destroy or prevent the integrity or fidelity of (a person) in his discharge of duty, to induce to act dishonestly or unfaithfully, to make venal, to bribe. Both definitions explicitly include bribery and encompass both the giving and receiving of bribes. 
The difficulty of a definitional uniformity stems from the fact that corruption involves activities or behaviors that are by their very nature secretive and usually illegal and secondly because it has many coloration, manifestation, dimensions and forms. While it may not be easy to define corruption, the origin of the word corruption according to Abdul-Isail (ND) can be traced to the Latin verb rumpere which means to break.

From this noble origin of corruption, many definitions of corruption have been put forward by scholars and practitioner alike. For example, Khan in his definition cited in Sorunke (2015) defined corruption as an act which deviates from the formal rule of conduct governing the action of someone in a position of public authority because of private regarding-motive such as wealth, power or status.

According to Nye, classical definition, corruption is defined as "behavior which deviates from the formal duties of public role. This includes such behavior as bribery (use of a reward to pervert the judgment of a person in a position of trust) nepotism (bestowal of patronage by reason of descriptive relationship rather than merit), and misappropriation (illegal appropriation of public resource for private-regarding uses)".

The World Bank defines corruption as "the abuse of public office for private gains" Corruption covers various forms of illegitimate interaction between public official and other agents. Sometimes, money is involved such as bribery or kickback for public contracts. In other cases, private gain can be non-monetary as in the case of patronage or nepotism. This definition also covers acts where there is no interaction with external agents, or where external agents are not explicitly implicated, such as the embezzlement of government resources or property.

It might also be interesting, to know that corruption also exists within and between private businesses and within non-governmental organizations, without any state agency or state official being involved. Besides, corruption also exists as a moral and cultural problem in the society, among individuals in their personal dealings. The level of "private" corruption can indeed by symptomatic for the general economic and political development of a society (Andvig and Fjeldstad 2000). Besides, all forms of private corruption can be destructive to the public morale and undermine the general trust and confidence in rules and regulation. Most definition of corruption will always emphasize corruption as a state-society relationship because public sector corruption is believed to be a more fundamental problem than private sector corruption and because controlling public sector corruption is a prerequisite for controlling private sector corruption.

\subsection{Empirical review}

Okoye and Gbegi (2013) examined forensic accounting as a tool for fraud detection and prevention in the public sector organization. Their study was conducted with reference to Kogi State in Nigeria; Data for the study were obtained from both primary and secondary sources. The use of questionnaire was complimented with oral interview. It was discovered from the study that the use of forensic accounting significantly reduce the occurrence of fraud cases in the public sector. It concluded that the use of forensic accountants can help better in detecting and preventing fraud occurrences in the public sector and therefore recommended that forensic accountants should replace external auditors in Kogi State.

In a study on the role of forensic accounting in reducing financial corruption carried out in Iraq by Tariq et al. (2014), the study adopted a correlation research design. Data were collected using interview and questionnaire. The main findings form the study revealed that there is a significant relationship between forensic accounting methods and effectiveness of control and auditing bodies to detect financial corruption cases. The study further revealed that majority of the audit and accounting personnel in Iraq are suffering from poor perception and information on forensic accounting methods. The study thus recommend that forensic accounting methods should be added to the curricula of accounting department in Iraq universities at both level of preliminary and higher studies through theoretical and practical classes.

In an empirical study by Dada (2014) titled, Forensic Accounting Technique: A means of successful eradication of corruption through fraud prevention, bribery prevention and embezzlement prevention in Nigeria; the research was able to establish that corruption prevention is significantly and positively related to fraud prevention, bribery prevention and embezzlement prevention through the application of forensic accounting techniques. It further revealed in the study that there is no forensic accounting unit in EFCC, and 
the professional firms that have forensic expertise are not consulted to carry out proper investigation of corruption cases. The study thus recommends that EFCC should set up a forensic accounting unit where trained expert should be employed to carry out investigation. More so, forensic accounting expert from the professional accounting firms should be retained by EFCC to carry out investigation and serve as expert witness that will assist the court to reach a conclusion on issues which the court itself may not have knowledge to decide.

In a study titled Fraud and the Nigeria Public Sector Performance: The need for Forensic Accounting, using personal interview and questionnaire administered on senior staff of Economic and Financial Crime Commission (EFCC), Independent Corrupt Practice Commission (ICPC) and Code of Conduct Bureau (CCB) by Adebisi and Gbegi (2015) empirically found that the application of forensic accounting skills and techniques in fraud investigation will build confidence in investor to come and invest, thereby bringing in social and economic development of the nation. The study further revealed that there is a positive and significant influence between the use of forensic accounting and the performance of the Nigerian public sector.

Umar et al. (2016) in their work titled Adoption of Forensic Accounting in fraud detection process by Anti-Corruption Agencies: A conceptual Framework was able to identify the probable factors that influence organization's decision to adopt forensic accounting in fraud detection process. This factor according to Umar et al 2016 includes the characteristics of the organization, environmental characteristics and top management background.

\section{Methodology of research}

Survey research design was adopted for this study. The survey research design was used, because according to Osuala (2001), survey design centers on people, their beliefs, opinion, attitude and behavior, while the survey questionnaire was used to elicit information on the use and potency of forensic accounting techniques in corruption investigation among the anti-corruption agencies in Nigeria. The exploratory technique i.e. the semi-structured interview was also used to complement, supplement and validate the data that was collected though the questionnaire.

The population of this study is made up of all the staff of investigative and prosecution units of the four anti-corruption agencies in Nigeria. The Economic and Financial Crimes Commission (EFCC), Independent Corrupt Practices Commission (ICPC), Code of Conduct Bureau (CCB) and Police Special Fraud Unit (PSFU).In considering sample size for a study from a target population, a number of methods can be used depending on the necessity of the research work. For the purpose of this present study, Yamane's formula for calculating sample size was used.

The techniques for analysis include descriptive and inferential analysis. Simple statistical tables with measures of central tendency (e.g. mean and median) and dispersion (e.g. standard deviation) was used to present the analyzed data from the questionnaire, while the hypothesis of the study was tested using Kolmogorov-Smirnov test. The K-S test shows the correlation between the P-value and the level of significance. Where the level of significance is greater than the P-value, we reject the null hypothesis while accepting the alternative hypothesis and vice-versa. The K-S test allows for an assertion which states that it impossible to prove that the null hypothesis is true.

\section{Results and hypothesis testing}

Adoption of forensic accounting techniques in corruption investigation has no significant and positive relationship with successful prosecution of corruption cases in law courts.

The below table presents the result of analyzed data using Kolmogorov-Smirnov test at 0.05 level of significant and the result made known a normal test distribution. The null hypothesis tested was rejected while the alternative was accepted because the P-values $(0.000,0.023,0.010$ and 0.000$)$ are less than 0.05 . The implication of this result is that the adoption of forensic accounting investigation techniques in corruption investigation in Nigeria will significant and positively ensures successful prosecution of corruption cases in law courts. 
Table 1. One-Sample Kolmogorov-Smirnov Test

\begin{tabular}{|l|c|c|c|c|}
\hline & $\begin{array}{c}\text { Adoption of forensic } \\
\text { accounting } \\
\text { investigation } \\
\text { techniques in } \\
\text { corruption } \\
\text { investigation helps } \\
\text { prosecutors to prepare } \\
\text { water-tight cases } \\
\text { against corrupt } \\
\text { officials. }\end{array}$ & $\begin{array}{c}\text { The use of } \\
\text { forensic } \\
\text { accounting } \\
\text { investigation } \\
\text { reports in } \\
\text { preparation of } \\
\text { corruption } \\
\text { charges do not } \\
\text { significantly } \\
\text { give better } \\
\text { interpretation } \\
\text { and } \\
\text { communication } \\
\text { of findings in } \\
\text { courts. }\end{array}$ & $\begin{array}{c}\text { Forensic } \\
\text { accounting } \\
\text { based } \\
\text { investigation } \\
\text { speeds up } \\
\text { successful } \\
\text { prosecution of } \\
\text { corruption } \\
\text { charges in } \\
\text { courts. }\end{array}$ & $\begin{array}{c}\text { Application of } \\
\text { forensic } \\
\text { accounting } \\
\text { investigation } \\
\text { techniques in } \\
\text { corruption } \\
\text { investigation is } \\
\text { an effective way } \\
\text { of securing } \\
\text { conviction in } \\
\text { corruption } \\
\text { charges in courts }\end{array}$ \\
\hline N & 130 & 130 & 130 & \\
\hline Normal Parameters mean & 3.99 & 3.08 & 3.79 & 4.05 \\
\hline Std. Deviation & 1.138 & 1.403 & .994 & 1.044 \\
\hline Most External Diff. Absolute & .295 & .181 & .314 & .241 \\
\hline Positive & .188 & .173 & .210 & .182 \\
\hline Negative & -.295 & -.181 & -.314 & -.241 \\
\hline Kolmogorov-Smirnov Z & 3.364 & 2.068 & 3.575 & 2.744 \\
\hline Asymp. Sig. (2-tailed) & .000 & .023 & .010 & .000 \\
\hline a. Test distribution is Normal & & & & \\
\hline
\end{tabular}

Source: Researcher's computation based on field survey (October, 2017)

\section{Conclusions}

This research empirically examined the potency of adopting forensic accounting investigation techniques in corruption investigation and successful prosecution of corruption cases in law court.

The summaries of major findings of this research are as follows;

(a) Adoption of forensic accounting investigation techniques in corruption investigation helps corruption prosecutors to prepare water-tight cases against corrupt officials.

(b) The use of forensic accounting investigation report in preparation of corruption charges significantly give better interpretation and communication of charges in courts.

(c) Forensic accounting based investigation speed up successful prosecution of corruption charges in courts.

(d) Application of forensic accounting investigation techniques in corruption investigation is an effective way of securing conviction in corruption charges in law courts.

(e) Adoption of forensic accounting investigation techniques in corruption investigation significantly and positively enhanced successful prosecution of corruption cases in law courts.

The need for the adoption of forensic accounting investigation techniques in investigation and prosecution of corruption cases in Nigeria has been successfully studied in this empirical research work. It was observed that politically corrupt officials will always get away with their loots unless the prosecutors can come up with water-tight corruption charges in courts. This can only be possible where appropriate investigation techniques are used.

The position of this paper is that adoption and application of forensic accounting investigation techniques in all public sector corruption investigation and prosecution will ensure conviction of corrupt officials in courts. In light of the findings from this study the following recommendations are made:

(1) All anti-corruption agencies in the country should set up a forensic accounting unit where trained expert should be employed to carry out investigation.

(2) Forensic accounting experts from the professional accounting firms should be retained by all the anti- corruption agencies to carry out investigations along with the organisation personnel and serve as 
expert witness that will assist the court to reach a conclusion on issues which the court itself may not have knowledge to decide.

(3) Forensic accounting experts should always be part of the prosecution team, so as to assist the prosecutors in building water-tight corruption charges against corrupt public officials.

\section{References}

1. Abudul-Ismail, A (ND): Corruption and its Treats to the Consolidation of Democracy in Nigeria: ThebShariah.

2. Adebisi J. and Gbegi D. (2015): Fraud and the Nigerian Public Sector Performance: The need for Forensic Accounting. International Journal of Business Humanities and Technology Vol. 5, No. 5 October 2015.

3. Adegbie, F and Fakile, A. (2012): Economic and Financial Crime in Nigeria: Forensic Accounting as Antidote: British Journal of Arts and Social Science Vol. 6, No. 1.

4. Adeyemi, O. (2012): Corruption and Local Government Administration in Nigeria: A discourse of Core Issues. European Journal of Sustainable development 1(2): 83-198.

5. Andvig, J, Fjeidstad, O, Amundsen, I, Sissener, T, and Sreid, T (2000): Research on Corruption: A Policy Oriented Survey. Ch. Michelsen Institute and Norwegian Institute of International Affair (NUPI).

6. Azih, N and Okoli, B. (2015): Forensic Accounting as a Veritable Tool for Efficient Management of State Owned Public Sectors in Ebonyi State: The Accountants' Perspective. British Journal of Education Vol. 3, No. 8, pp 55-62

7. Bhasin, M. (2013): Survey of Skills Required by Forensic Accountants: Evidence from a Developing Country. International Journal of Contemporary Business Studies, 4(2) pp. 54-86.

8. Chattopadhyay, P (2014): A Theoretical Construct of Forensic Accounting and Auditing. The Management Accountant September 2014, pp. 22-28

9. Dada, S. (2014): Forensic Accounting Technique: A means of Successful Eradication of Corruption through Fraud Prevention, Bribery Prevention and Embezzlement Prevention in Nigeria. Kuwait Chapter of Arabian Journal of Business and Management Review. Vol. 4, No.1 September, 2014.

10. Davis, C., Farrell, R. and Ogilbly, S. (2010): Characteristics and Skills of the Forensic Accountant. American Institute of Certified Public Accountant.

11. DiGaabriele, J. (2009): Fishbowl of the Forensic Accountant: A Closer looks at the Skills of Forensic Accounting Education Should Emphasize. The Forensic Examiner, 18(2), pp. 77-79

12. Grippo, F and Ibex, T. (2003): Introduction to Forensic Accounting. National Public Accountant, 4, $\mathrm{Pp} 4-8$.

13. Harris, C and Brown, A (2000): The Qualities of a Forensic Accountant Pennsylvania CPA Journal, 71, Pp 2-3

14. Hopwood, W, Leiners, J. and Young, G. (2008); Forensic Accounting. New York: McGraw Hill/Irwin.

15. Howard, S. and Sheetz, M. (2006) Forensic Accounting and fraud Investigation for Non-Experts. New Jersey: John Wiley \& Sons Inc.

16. Horrby, A. (2000): Oxford Advanced Learner's Dictionary of Current English $6^{\text {th }}$ ed. Oxford: Oxford University Press.

17. Messmer, M (2004): Exploring Option in Forensic Accounting National Public Accounting, 5, pp. 9- 20.

18. Modugu, K and Anyaduba, J. (2013): Forensic Accounting and Financial Fraud in Nigeria: An Empirical Approach. International Journal of Business and Social Science. Vol. 4 No. 7 July 2013.

19. Obasanjo, O. (2017): Comment on Loss of Vital Corruption Cases by EFCC; Punch Newspaper, $2^{\text {nd }}$ May, 2017

20. Okoye, E, and Gbegi, D. (2013): Forensic Accounting: A Tool for Fraud Detection in Public Sector (A Study of Selected Ministries in Kogi State). International Journal of Academic Research in Business and Social Sciences. March 2013. 
21. Omar, N. and Jomitin, B. (2013): The Relevance of Forensic Accounting in Public Sector (A Study of Selected Government Agencies in Klang Valley). The $5^{\text {th }}$ International Conference on Financial Criminology (ICFC) 2013 “Global Trends on Financial Crimes in the New Economies, pp. 225- 232.

22. Osuala, E. (2001): Introduction to Research Methodology, $3^{\text {rd }}$ edition Onitsha Nigeria, African FEP Publisher Ltd.

23. Ramadhan, S. (2015): Certified Accountants' Perception of Forensic Accounting Education: The Case of Bahrain. International Journal of Finance and Accounting 2015, 4 (2) $109-118$.

24. Ramaswamy, V. (2011); New Frontiers: Training Forensic Accountants within the Accounting Program. Journal of College Teaching and Learning (TLC), 4, (9), pp. 31-38.

25. Sorunke, O. (2015): corruption and Foreign Direct Investment in Nigeria: A Survey of Foreign Investors. International Journal of Investment and Finance Vol. 8 No. 1 \& 2 pp. 1-14.

26. Sorunke, O. (2016): Integrating Forensic Accounting in Accounting Curriculum in Nigerian Universities: Challenges and Remedies. International Journal of Academic Research in Progressive Education and Development Vol. 5, No. 1, pp. 59- 64.

27. Sukamal, B (2014): Forensic Accounting in the Cyber World: A New Challenge for Accountants. The Management Accountant September 2014, pp. 18-21.

28. Tariq, T,. Moayad, M, Sofri, $Y$ and Ala M. (2014): The Role of Forensic Accounting in Reducing Financial Corruption: A Study in Iraq. International Journal of Business and Management Vol. 9, No.1, 2014.

29. Umar, I shamsiahBtsamsudin, R. and Mohamed, M (2016): Adoption of Forensic Accounting in Fraud Detection Process by Anti-corruption Agency: A Conceptual Framework. International Journal of Management Research and Review. Vol. 6 (2) 139-148.

30. World Bank (2000): Reforming Public Institutions and Strengthening Governance: A World Bank Strategy. Washington, DC. 